\title{
Preference of institutional changes in social and economic development
}

\author{
Mimo Draskovic \\ Maritime Faculty Kotor, University of Montenegro, \\ Montenegro \\ Email:rookie@t-com.me
}

\section{Delibasic Milica}

University of Business Engineering and Management,

Bosnia and Herzegovina

Email:23.mildel@gmail.com

\section{Ivic Mladen}

University of Business Engineering and Management, Bosnia and Herzegovina

Email:ivic.mm81@gmail.com

\section{Oksana Chigisheva}

Southern Federal University, Rostov-on-Don, Russian Federation

Email:opchigisheva@sfedu.ru

Abstract. S. Kuznets wrote that structural changes are the central element in the process of development and the most important part of the growth model. They can hinder the growth, if carried out too slowly or inefficiently, but they can also promote economic growth if the distribution of resources gets better. The article has presented the authors' attempts to present new approaches to modeling the institutional behavior of economic agents. Different approaches and views on economic growth and economic development in their application to institutional changes are considered. The descriptive method explains the hypothesis of the dominant role of social innovations (primarily institutional changes) in social and economic development. Significance of sociocultural capital in the context of contemporary knowledge economy is potentiated. The conclusion is that transition countries must use exemplary models and civilization achievements of institutional changes in developed countries.

Keywords: institutions, institutional changes, economic development, economic growth.

JEL Classification: D02, O10, O17, P37 


\section{INTRODUCTION}

The opening note of this article clearly shows that most of S. Kuznets' economic ideas concerned economic growth. However, here we still need to keep in mind some other statements of the same author (e.g., Kuznets, 1996, p. 445): without political democracy and civil freedoms implementation of real institutional changes will be impossible. This obviously shows that the overall situation around economic growth is not simple and depends on many factors at the same time. Moreover, dynamic interdependencies here exact not only between the factors of economic growth but also between its key elements. We can present economic development as a sum of: economic growth, long-term prospective, structural changes, institutional changes and environmental sustainability. And interrelation of structural and institutional changes should be considered exactly in this context. Apart from this, in this article we stem from the popular today view of the neoinstitutionalists (for example, North, 2005) that institutional changes must be in priority to structural changes.

On the top of that, we will be operating S. Kuznets' ideas concerning the role of structural changes and also his rather smart idea that without the human factor/capital and the processes of its reproduction economic development simply cannot be modelled or tracked. On the ideas of Kuznets we can track the evolution in understanding the importance of social sphere (social structures) which essentially requires institutes and also takes part in their formation, so that later institutes can serve as regulators, coordinators and limiters of human and organizational behavior. Besides that, institutes are forming a flexible supporting structure (or set of structures) for further interaction of individuals joined into special-interest groups.

Kuznets' views have been widely discussed, supported and/or opposed, in literature, especially his idea to treat economic development by certain periods. These periods are connected to economic \& technological cycles which Kuznets himself named "long swings" (Kuznets, 1958). Later on, another famous economist and the Nobel prize winner of 1979 U.A. Lewis called those „Kuznets cycles“ already (according to: Abramovitz, 1966, p. 520). Here we also would like to quote another of his rather interesting thoughts, namely, that „contemporary economic growth forces us to take action so that to solve the emering conflicts and also in relation to always newly created changes in economy and social structure... Continuity of technological innovative features in today's economic growth and in social innovations eases the necessary adaption and is probably the most important factor impacting economic and social structure" (translated from Russian, quote from Laureaty Nobelevskoy premii po ekonomike, 2007, p. 98).

Thus, we can state that Simon Kuznets was among the first (or maybe even the very first) to use the term „social innovations“. And in our article here we will try to analyze those so that to determine how these social innovations are related to institutional innovations. This is especially relevant and highly important for the post-socialistic countries, most of which are still having troubles with reaching a decent rate of economic growth and/or economic development. In other words, studying similarities and differences between thes two notions we would like to try to explain the key reasons behind the obvious failures of post-socialistic reforms. At this, we initially assume that one of the key reasons for these failures is the deficit of institutional changes (institutional innovations), to which - probably - also belong social innovations. This deficit has led to many contradictial or even paradoxal phenomena and also so-called pseudo-innovations (which proved to be not temporary, as it was believed earlier (V. Polterovich (2012), moreover, they directed the transition process into a long-term and complex crisis).

Many authors are applying the institutional approach when studying social capital (see e.g. Čábelková \& Strielkowski, 2013; or Čábelková, 2015). In this way they are able to discuss means and methods with which formal and informal institutes influence social capital accumulation in the society or a social group. Studies of many authors have already proved that sustainable economic development is possible only under close partnership and cooperation of private business, society and the state (Niño-Amézquita et al., 2017). 
At this, the state is not only creating social benefits but it also helps forming long-term and efficient alliances of various social groups and strata. In the countries with well-developed institutional pluralism there is always strong social consensus which is essentially the balance of interests of various social classes and groups when it comes to social product distribution, setting the minimum wage, transfer payments' allocation etc. This social consensus guarantees there exists a certain level of social welfare which further promotes investments' growth, better investment climate, high rate of economic growth, etc. (Koudelková et al., 2015; Nawrot, 2015)

And again, S. Kuznetz (1995) studied the relation between economic growth and social inequality. While studying this relation it is important to pose the following questions: what is the role of the state (represented by political and tax authorities) in wealth distribution? And what is the mission of social capital in this regard? There can be many answers to that, actually. Some researchers outline four vital elements in these relations: social networks, general norms, values and trust. Some other scientists are of the opinion that three elements are needed for institutional relations - social networks, general norms and convictions, and also two factors more are necessary for social capital formation - trust and rules (at all social levels). Another additional factor of important influence is also experience (Figure 1).

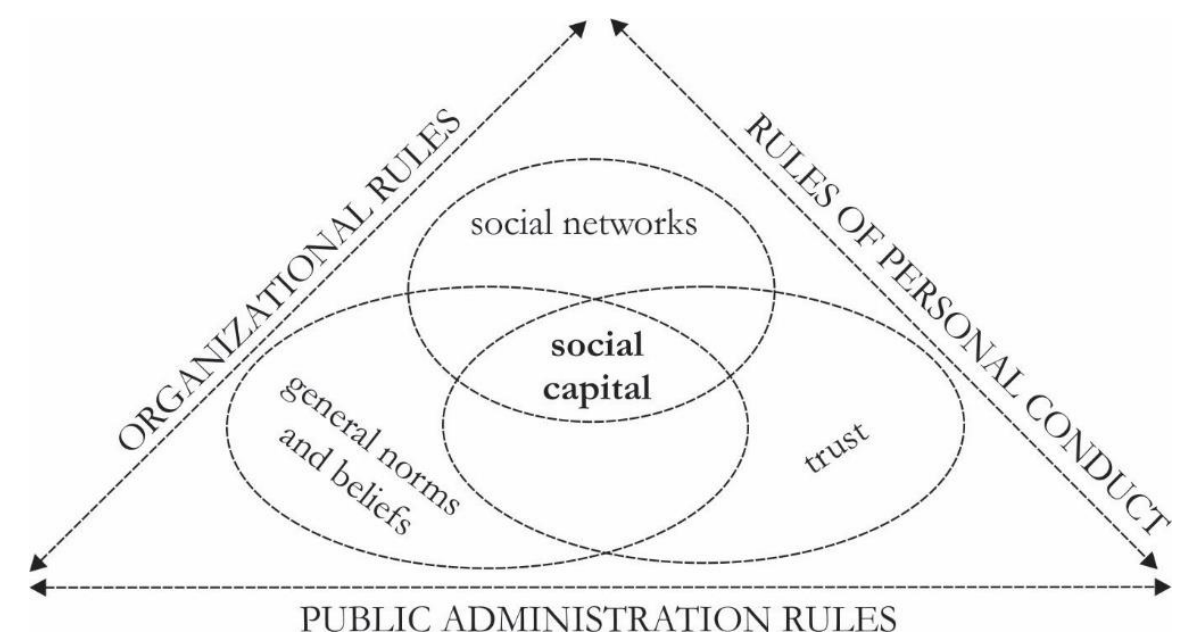

Figure 1. Social capital components

Source: V. Draskovic, R. Jovovic, M. Draskovic and B. Jereb, 2013, p. 124.

\section{THEORETICAL APPROACHES TO THE ROLE OF SOCIAL INNOVATIONS (INSTITUTIONAL CHANGES) IN ECONOMIC DEVELOPMENT}

As of today there is a general consensus in scientific circles concerning the overall importance of institutes and their leading role in the development of national economy. But what is exactly their role and how relevant it can be in relation to different levels and rates of economic development - this still needs to be studied in more detail, since despite quite intensive theoretical research and avalaibility of substantial empirical material, there is still no clear understanding why institutes are so important for economic growth. One of the possible reasons for this gap in the related research is lack of theoretical basis for application of institutional notions and also the impossibility of measuring exactly (that is, calculating) the influence of institutes. As well noted by D. Acemoglu (2009) it can be partially explained by the fact that very notion of institute is defined in literature (see, for example, Greif, 2006; Hodgson, 2006) as too broad, and the range 
of institutional forms and manifestations is also too broad, thus, it is rather difficult to allocate them a specific place as applied to economic results.

Institutional changes and economic growth are, most probably, the most important components and preconditions for economic development. However, this leads us logically to a question regarding casual relations here: what is causing what in these relations, what is the cause, and what is the consequence institutes or development? These questions remain open for quite a while already. However, there is a popular opinion that institutional shifts go first, then follows development (see e.g. Strielkowski \& Č́belková, 2015). Another, and also popular, opinion is that development determines the institutes (which are in some sort of compliance with the actual level of economic system development). Both options are equally convincing on paper (Chang Ha-Joon, 2005, 2011). The very history of many developed countries supports the second variant, actually: in these countries the achievements of economic development opened the way for further modernization of many institutes and formation of the institutional system as such, and the latter quickly became relevant not as much to the developed economy, but more to the very strive for further economic development, thus forming the need for further economic growth (Yerznkyan, 2013). Taking this into account, we also need to note that the view on high and stable rates of economic growth as the key factor of general social welfare increase and stabilization is not only popular but also has solid empirical support. Besides, this view also complies with the central ideas of Kuznets' teachings.

Representatives of the new institutional economic theory (North, 1981, 1990) have already provided enough proof that pluralistic, politically desirable and legally protected institutional environment predetermined long-term economic growth. In other words, stably high rates of economic growth are not cauasing institutional changes, on the opposite - they are the consequences of these changes. Rapid changes in economic realia of the two recent decades, predetermined by exponential technological and organizational changes and also by some of the global processes, have lead to paradigmal modifications in the economic growth model.

The neoclassical model of growth by R. Solow (1956) emphasized the key role of technological progress, and its author added to the already existing models (which used to emphasize the role of physical capital and laborforce) the technological factor. According to his calculations, technological factor predetermined about $4 / 5$ of growth in case of American economy when calculated per one worker/employee. R. Lucas (1988) emphasized the role of human capital, while R. Barro and Sala-i-Martin (1997) described the meaning and role of technological diffusion. R. Barro (1990) also studied the role of social infrastructure, while P. Romer (1990) described the role of innovation stimuli etc.

The contemporary theories of economic growth mention the following key decisive factors: institutes, innovations, information (and some other) technologies and intellectual/human capital. This means that here we can talk about the „model of four" which reveals the causes of economic growth (Delibasic, 2014, p. 9).

As presented by D. North (1997, p. 17), institutes are the ,game rules“ for the society. Or, speaking more formally, they are the limiting framework established by the people so that to organize and regulate the relations between themselves. Therefore, these rules/frames are shaping all further incentives for human interaction in any field - politics, social life or economic activities. In other words, this capacity of the institutes to shape and structure social stimuli tells us, simply speaking, that any possibility of free individual choice is, to a large extent, predetermined and limited by institutes. Social (inlcuding political, traditional, moral, cultural and other) as well as economic institutes are directly and indirectly influencing on the structure of economic incentives inside the society. D. North assumes that interpretation of institutes can be actually two ways: institutes as informal limitations in a society (generally accepted norms, rules and certain code of conduct) or institutes as formal (that is, created and introduced by people) rules. 
Informal institutes have the determining influence on our behavior. As same D. North one wrote, the latter is to a great extent determined by the unwritten codes, norms and formalities (Ibid, p. 56) which usually emerge from the information transmitted via certain social mechanisms and are part of that legacy which we call culture (Ibid, p. 57). Cultures as our heritage are able to explain why formal institues, under different circumstances, can lead to rather different results. Formal institutes (or, as D. North calls them rules) include political (and legal), economic rules and contracts. These rules have their own hierarchy from constituions to statutes, then to legislative acts and regular laws, then go decrees and orders, and finally individual contracts and agreements. This overall hierarchy of rules poses both general and specific limitations (Ibid, p. 68). D. Acemoglu, S. Johnson and J. Robinson (2004) proved, in this regard, that societies with the economic institutes which promote the accumulation of innovation factors and increase the efficiency of resources' distribution, have more chances to reach prosperity, and vica verse.

\section{THE ACCOMPANYING CONCEPT OF SOCIOCULTURAL CAPITAL}

Human is a social being and an inseparable element of social environment. This is why any human is motivated not only by his/her own interests but also by habits, traditions and rituals, changes in the society etc. Institutes are also important components of the same social environment.

The concept of sociocultural capital (sociocultural factors and social relations) explains the role of individual and organizational social relations, collective actions and social integration as applied to development. Sociocultural capital as a set of mostly informal institutes and social habits (which are certain ethical, cultural, religious and civilizational values) predetermines all social changes - and thus, also predetermines social and economic development (Acemoglu et al., 2003; North et al., 2009; Fukuyama, 2004, p. 21; Patnem, 1996, pp. 207-209). However, if this sociocultural capital is under the dominating influence of public authorities - it can quickly become its own complete opposite - the barrier to development, because economy and politics are closely interconnected in real life and tend to absord the sociocultural capital, as stated in (Fukuyama, 1995, 2001).

Sociocultural capital includes knowledge, with its complex of normative means for knowledge integration and identification, development, education, organization, communications etc. Sociocultural capital has the capacity to mobilize and combine the capacities of individual and collective subjects. In its traditional meaning, sociocultural capital is defined by the following factors: morale, ideology, culture, religion, political regime, authority and trust to authorities, history of institutional changes, social connections, knowledge and investment in knowledge (and/or in human capital) etc. This set of inmaterial social resoures is essentially the environment surrounding and connecting both formal and informal institutes. Such comprehensive understanding of the notion "sociocultural capital“ may serve as a methodological and analytical connection between the notion „social innovations“ and ,institutional innovations" (which are essentially institutional changes). Disregarding all their similarities and differences, we are of the opinion that the deficit of all these innovations has lead to evolutionary crisis during the transition phase in the post-socialistic countries and thus has also lead to restoration of some sort of quasiinstitutional monism (which is also quasi-market-oriented and quasi-liberal).

Due to mostly neglected role of sociocultural capital during the whole transition stage in the postsocialistic countries, their economies and societies found themselves following some sort of antidevelopment model which is essentially very paradoxal (Draskovich et al., 2016, pp. 103-111). Why did this happen? Because the quality of sociocultural capital determines the level of real institutional changes. It is sociocultural capital that provides sustainability to all institutes and development overall. Institutes as the standards and regulators of individual behavior are determining the general direction of socioeconomic 
development. Together with people, institutes are important components of social environment. There is enough empirical material and detailed research to prove that in the majority of post-socialistic countries institutes have been developing very slowly, often insufficiently and also illogically, moreover, they were often under the influence of alternative institutes. Many authors, including (Draskovic, 2014; Draskovic et al., 2015; Delibasic, 2016; Draskovic, Draskovic, Bilan \& Delibasic, 2016) see the major precondition for such development in the anti-productive and anti-civilizational development of sociocultural capital as well as in parallel domination of alternative (shadow) institutes, the latter getting only stronger due to growing dominance of narrow, personal incentives over the truly social interests. Therefore, we have no doubts that the deficit of institutes is the major limiting factor in the potential development of sociocultural capital in these countries, thus, it is also a limiting factor for their socioeconomic development. Subjective (alternative, and in some radical cases - simply criminal) institutes tend to ignore institutional norms of behavior and all institutional changes as such. Dominance of these alternative institutes in the society proves there can be institutional irrationality (Draskovic, 2014; Delibasic, 2014).

So, the key question is: who is to be blamed for this deformation of institutional structure and/or for institutional underdevelopment which hinders all further development? Different authors suggest different answers to this question, however, the most known and acknowledged economists (e.g., North, 1981; Denzau, North, 1994; Friedman et al., 1998; Acemoglu et al., 2003; North et al., 2009) mention in this regard the destructive nature of institutional imitations and some sort of "government improvisations". Most of these authors are of the opinion that it is necessary to reduce and control the dominating influence of politics over economy, moreover, institutes are supposed to dominate both - political and economic life. It would be quite appropriate to mention here M. Mann (2014) who proved that actions of central authorities in underdeveloped countries are predetermined by an intricate combination of political, economic and ideological sources. So, how did this happen? Public authorities indeed have been using the neoliberal model, but only with the ideological purposes! Economic neoliberalism has made the institute of public regulation the key enemy of the society. Economic radicalism is now being implemented under the slogan of "minimum intrusion of the state". In fact, the market is mostly being ignored, except for those cases when specific interests of some small privileged groups must be followed. Market today is being substituted by the distributive coalitions and raider ideologies of quasi-neoliberalism (Draskovic, 2010, 2014; Jovovic, 2012; Draskovich M., Draskovich V. and Bilan, 2016). And these small groups of the most privileged are parasiting on public policies' use in their own interests, substituting the real market mechanisms by the monopolistic quasi-competition and semi-legal acquisition of public property. Thus, these small groups are using non-market methods for own enrichment, and this lead the majority to perceive public authorities, all public policies and actions as the acts of "predatory state" (Marcouiller and Young, 1995).

This perverted individualism of the few most priviliged has quickly found its own placed as a socially approved norm. This, in turn, has lead to quick spread of opportunistic behavior, network corruption and other forms of alternative social institutes. Some authors (e.g., Landes, 1998, p. 516; Draskovic, 2014, p. 22) explain these trends by the underdevelopment of sociocultural capital. Moreover, further spread of these alternative institutes has led to further erosion of sociocultural capital and as a result - to constant reproduction of economic and social crises, with already typical accompanying consequences: value crisis in the society, dogmatism, negative selection, poverty, inequality and unfair selection, neglection of legislation, inflexibility of public bodies to change etc. 


\section{ECONOMIC DEVELOPMENT UNDER „KNOWLEDGE ECONOMY“}

Within the „knowledge economy“ (also known as „,new economy“) the role of intellectual component of capital is growing every day. Information as the most obvious intangible factor today predetermines the use of new communications and their convergence. This, in turn, leads to society consolidation in many fields of economic and social activities. The growth of information economy has its own, new organizational logic which is preconditioned by the ongoing process of technological change. Introduction and full functioning of knowledge economy has certain preconditions, namely, there must be national guarantees for social freedom, and also well-developed system of education, high quality of institutional environment overall and very specific rules of doing business, as well as reasonable balance between state control and market freedom. Lack or underdevelopment of any of these components make „knowledge economy“ just a vox, and nothing else.

Today, in the era of knowledge economy, any national economic policy must rest on the following core principles: a) development of sciences and technologies must be the core factor of economic growth; b) favourable investment climate must attract investments, and mainly into the top-priority high-tech sectors; c) institutional environment must be flexible enough in all sectors of the economy (the so-called institutional pluralism), especially when it comes to national regulation which must be always ready to respond promptly and adequatly to market failures, especially when these failures are somehow related to education and science; d) competitiveness of production capacities must be supported by means of stimulating innovations related to higher performance and/or labor productivity; e) human resources at key productions must be timely and adequatly retrained so that to be ready to respond to risks, sudden changes and crisis; f) all new organizational changes must positively contribute to the economy, social life and/or legal field.

The overall structure of knowledge economy consists of human capital, information \& communication technologies, innovations and some other components (for more details - see Figure 2).

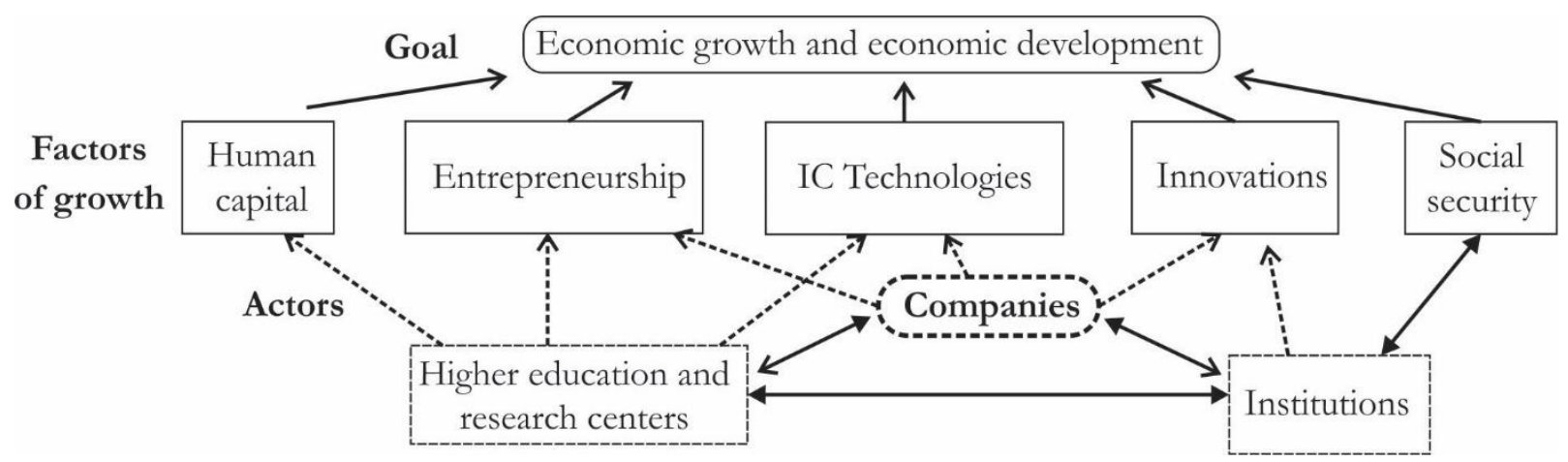

Figure 2. The model of economic growth and economic development under „knowledge economy“"

Source: Cornett, 2009, p. 405.

Factors with dominating influence on economic development (according to our literature review) are presented in Figure 2. As we can see, stable development depends on a whole range of driving forces, including: access to human capital, quality and rate of innovations, availability of soft and hard infrastructure, current rate of welfare, institutional structures and finally, entrepreneural activity (Cornett, 2009; Naudé et al. 2008; Audretsch and Keilbach, 2004).

Assuming that the following statements are true: 
a) institutional development has its positive influence on economic growth and economic development;

b) economic development directly (through better motivation and more active investment in education and sciency) as well as indirectly (through creation of better living conditions: high wages for researchers, scientists and engineers; better communications and more access to information and statistics etc.) influences the growth of expert knowledge and innovations,

we can make a conclusion that there exist indeed strong interdependencies and feedback relations, as demonstrated in Figure 3 (social innovations are shown with curved arrows).

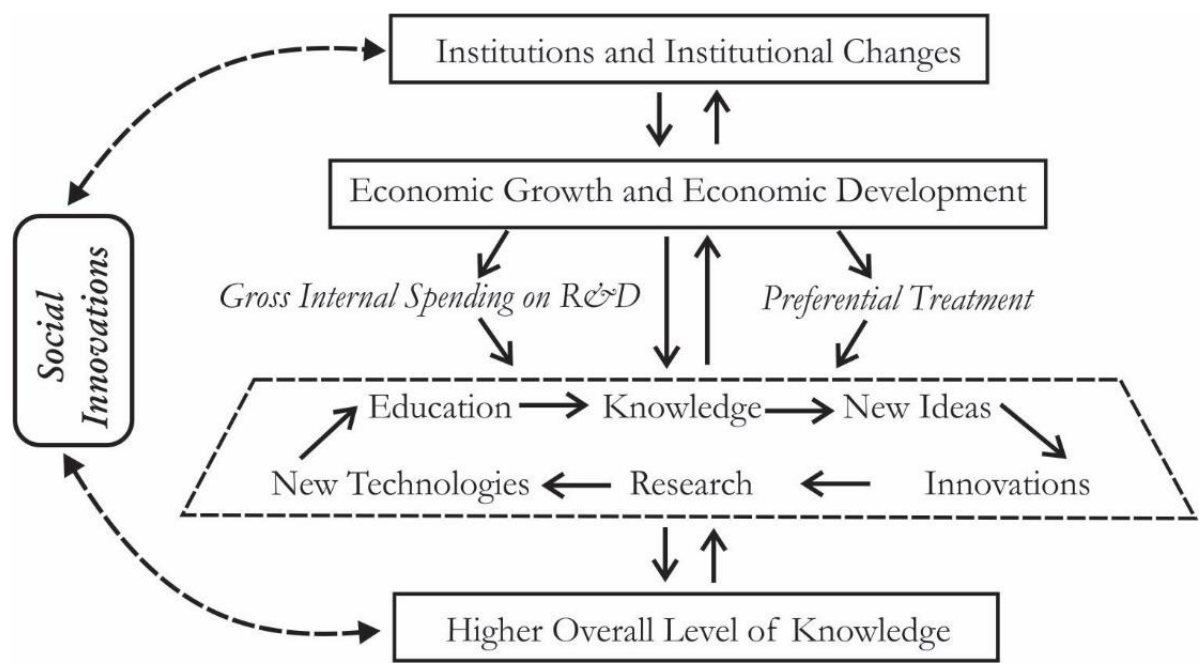

Figure 3. Social innovations and the development formula within knowledge economy Source: V. Draskovic, R. Jovovic and M. Draskovic, 2013, p. 17

The dependence „institutes - economic development - investments in knowledge - innovations increased level of knowledge" can be analyzed and interpreted in many different ways, however, their mutual dependence is already real and meaningul in today's economic reality, and for this matter we are indeed living in the times of ,knowledge economy“.

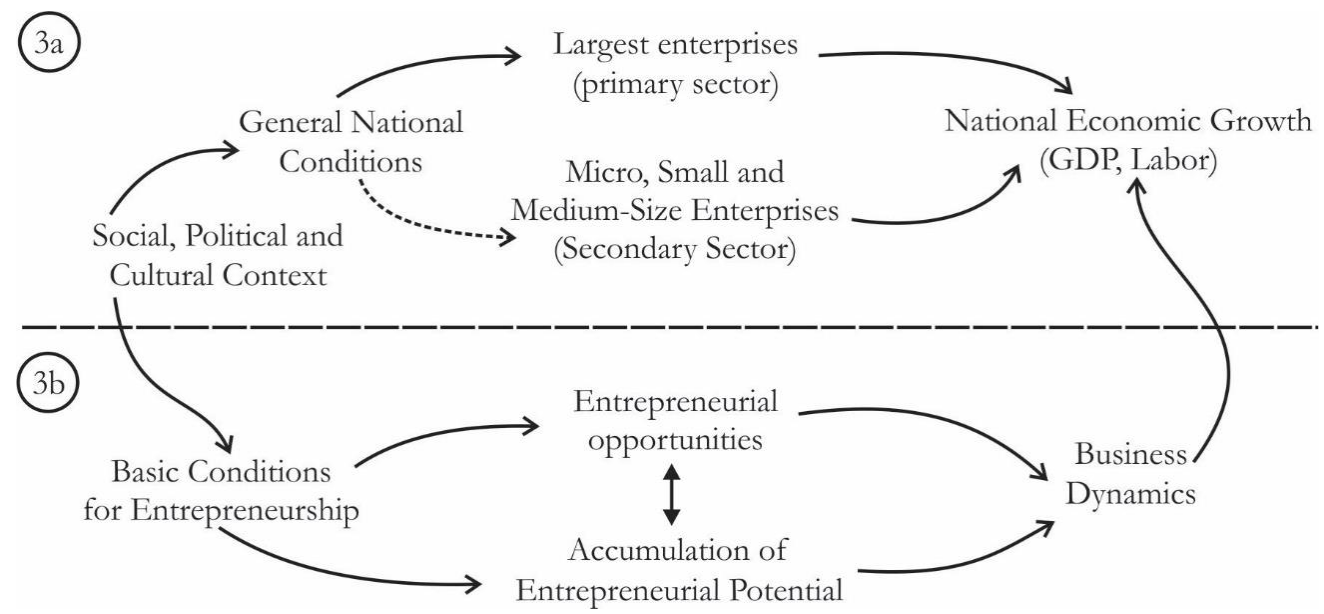

Figure 4. GEM's conceptual model of economic growth 
Source: Reynolds, 1999, pp. 9-10; Global Entrepreneurship Monitor 2014 Global Report, pp. 13-14.

The conceptual frameworks of GEM have been defined in 1999 (Figure 4), and unlike more traditional models of national economic growth, the former clearly shows that national economy's growth is the results of human efforts and availability of opporunities to take these efforts. It also shows that this process is taking place in the interaction with the environment.

\section{CONCLUSION}

Many theoretical and empirical studies have already discovered and proved there exists a direct correlation between institutional development of a country and its economic development (D. North, D. Acemoglu et al.) as well as between the level of knowledge and economic development. On these grounds we can assume that it would be logical to unite the cause-effect relations here: development based on knowledge (and investments in knowledge), institutes and their changes, economic development and economic growth - and this article we presented this graphically, inter alia.

This constant interconnection of various spheres - institutional, economic, social, cognitive etc. - is the necessary precondition for the formation of some sort of platform for further modelling of institutional behavior of economic agents. This modelling is supposed to be adequate to the actual real situation, specifically - in the countries of post-Soviet and post-socialistics space. At the same time, such modelling attempts must not be limited to economies in transition only. We assume that modelling of institutional behavior of the economies would have some common features, regardless the history of a country and the level of its economic development.

\section{REFERENCES}

Abramovitz, M. (1966). Readings in business cycles selected by a committee of the American economic association. London, George Allen \& Unwin Ltd.

Abramovitz, M. (1986). Simon Kuznets (1901-1985). The Journal of Economic History, 46(1), 241-246.

Acemoglu, D. (2009). Introduction to Modern Economic Growth. Cambridge, MA, Princeton University Press,

Acemoglu, D. et al. (2003). Institutional causes, macroeconomic simptoms: volatility, crises and growth. Journal of Monetary Economics, 50, 49-123.

Acemoglu, D., Johnson, S. \& Robinson, J. (2004). Institutions as the fundamental cause of long-run growth. Working Paper 10481, 385-472. NBER, Cambridge, MA. Retrieved from http://www.nber.org/papers/w10481

Audretsch, D., Maryann, B. \& Feldman, P. (2004). Knowledge spillovers and the geography of innovation. Handbook of regional and urban economics, 4, 2713-2739.

Barro, R. J. (1990). Government spending in a simple model of endogenous growth. The Journal of Political Economy, 98/5(2), 103-125.

Barro, R. J. \& Sala-i-Martin, X. (1997). Economic Growth. Cambridge, Mass., MIT.

Cornett, A. P. (2009). Aims and strategies in regional innovation and growth policy - A Danish perspective. Entrepreneurship \& Regional Development, 21(4), 399-420.

Chang Ha-Joon (2005). Globalization, global standards and the future of East Asia. Global Economic Review, 34(4), 363378.

Chang Ha-Joon (2011). Institutions and economic development: theory, policy and history. Journal of Institutional Economics, 7(4), 473-498.

Ćábelková, I., \& Strielkowski, W. (2013). Is the level of taxation a product of culture? A cultural economics approach. Society and Economy, 35(4), 513-529. doi:https://doi.org/10.1556/SocEc.2013.0007

Ćábelková, I., Strielkowski, W., \& Mirvald, M. (2015). Business influence on the mass media: a case study of 21 countries. Transformation in Business \& Economics, 14(1), 65-75. 
Delibasic M. (2014). The post-socialist transition through the prism of O. Williamson's insight. Montenegrin Journal of Economics, 10(1), 13-24.

Delibasic, M. (2016). Hypothetical matrix for institutional modeling of the basis for economic development in the countries of Southeast Europe. Montenegrin Journal of Economics, 12(2), 147-159.

Delibashich, M. \& Grgurevich N. (2014). K modelirovaniyu institutsional'nogo povedeniya. Teoriya $i$ praktika institutsional'nykh preobrazovaniy $v$ Rossii, 28, 6-18 (in Russian).

Denzau, A. T. \& North, D. C. (1994). Shared mental models: ideologies and institutions. Kyklos, 47(1), 3-31.

Draskovic, V., Jovovic, R., Draskovic, M. \& Jereb, B. (2013). Knowledge - keystone of the modern economy. Celje, Osijek, Czestochowa \& Kotor, SPH.

Draskovic, M., Grgurevic, N., \& Delibasic, M. (2015). Institutional properties of the Southeast European region. Economy of Region, 3(43), 17-24 (in Russian)

Draskovic, M, Draskovic, V., Bilan, Y. \& Delibasic, M. (2016). Quasi-Neoliberalism as quasi-institutional monisms and causes of the crisis in South-Eastern Europe. Transformations in Business \& Economics, 15/3(39), 39-52.

Draskovic, M., Bauk, S., \& Delibasic, M. (2016a). Testing the level and factors of institutional rationality in Montenegro, Serbia and Bosnia and Herzegovina. Economics and Sociology, 9(2), 22-40.

Draskovic, V. (2010). The real institutionalization as a condition of the efficient economic politics and economic development. Montenegrin Journal of Economics, 7(1), 5-20.

Draskovic, V. (2014). Neoliberal Metaphor. As a quasi-economic paradigm in function of vulgarized institutional monism and an experiment of interest. Celje, Osijek, Czestochowa \& Kotor, SPH.

Draskovic, V., Jovovic, R., \& Draskovic, M. (2013). Depedence paradigmatic of 'knowledge economy' from level of institutional and economic development. Economics \& Economy, 1(1), 7-30.

Drashkovich, M. Drashkovich, V., \& Bilan, Y. (2016). Sotsial'no-ekonomicheskiye faktory, tormozyashchiye razvitiye: opyt stran Yugo-Vostochnoy Evropy. Sotsis, 4(396), 103-111.

Frydman, R., Rapaczynski, A., \& Murphy, K. (1998). Krade se država, pa i sve u njoj. Banka, 9(11), 63-67.

Fukuyama, F. (1995). Trust: social virtues and the creation of prosperity. New York, Free Press.

Fukuyama, F. (2001). Social capital, civil society, and development. Third World Quarterly, 22(1), 7-20.

Fukuyama, F. (2004). Doveriye: sotsial'nyye dobrodeteli i put' k protsvetaniyu. ACT Publ., Moscow: Yermak (in Russian).

Global Entrepreneurship Monitor 2014 Global Report (2014). Retrieved from http://gemconsortium.org/report (21.01.2017)

Greif, A. (2006). Institutions and the Path to the Modern Economy. Cambridge. Cambridge University Press.

Hodgson, G. M. (2006). Institutions, Recessions and Recovery in the Transitional Economies. Journal of Economic Issues, 15(4), 875-894.

Jovovic, R. (2012). Global financial crisis: role of international institutional framework, and lesson for transitional countries. Montenegrin Journal of Economics, 8(3), 65-76.

Koudelková, P., Strielkowski, W., \& Hejlová, D. (2015). Corruption and System Change in the Czech Republic: Firmlevel Evidence. DANUBE: Law and Economics Review, 6(1), 25-46. doi: https://doi.org/10.1515/danb-2015-0002

Kuznetz, S. (1958). Long swings in the growth of population and in related economic variables. Proceedings of the American philosophical society, 102(1), 25-52.

Kuznets, S. (1995). Economic growth and Income inequality. American Economic Review, March, 1-28.

Kuznetz, S. (1996). Modern economic growth. rate, structure and spread. How Haven and London, Yale University Press.

Landes, D. S. (1998). The wealth and poverty of nations: why some countries are so rich and some sopoor. New York, W. W. Norton.

Laureaty Nobelevskoy premii po ekonomike: $v 3$ t. (2007). Nauch. red. V.V. Okrepilov, 1, 1969-1982. Moscow, SPb.: Nauka(in Russian).

Lucas, R.E., Jr. (1988). On the mechanics of economic development. Journal of Monetary Economics, 22(1), 3-42.

Mann, M. (2014). Vlast v XXI stoletii. Moskva, Vysshaya shkola ekonomiki (in Russian).

Marcouiller, D., \& Young, L. (1995). The Black hole of graft: the predatory state and the informal economy. American Economic Review, 3, 630-646.

Naudé, W., Gries, T., Wood, E., \& Meintjies, A. (2008). Regional determinants of entrepreneurial start-ups in a developing country. Entrepreneurship and Regional Development, 20(2), 111-124. 
Nawrot, K. (2015). Capabilities of leapfrogging and catching up of a developing country - policy implications from theory and practice, International Economics Letters, 4(4), 115-123

Niño-Amézquita, J., Dubrovsky, V., Jankurová, A. (2017). Innovations and competitiveness in regional development: a comparison of Latin America, Europe, and China. Czech Journal of Social Sciences, Business and Economics, 6(1), 28-

36. doi:https://doi.org/ 10.24984/cjssbe.2017.6.1.4

North, D. C. (1981). Structure and change in economic history. New York, W. W. Norton \& Co.

North, D. C. (1990). Institutions, institutional change and economic performance. New York, Cambridge University Press.

Nort, D. (1997). Instituty, institutsional'nyye izmeneniya i funktsionirovaniye ekonomiki. Moscow, Fond ekonomicheskoy knigi „Nachala“ (in Russian).

North, D.C. (2005). Understanding the Process of Institutional Change. Princeton, Princeton University Press.

North, D.C., Walis, J. J., \& Weingast, B. R. (2009). Violence and Social Orders - A Conceptual Framework, for Interpreting Recorded Human History. Cambridge, The Syndicate of the Press.

Patnem, R.(1996). Chtoby demokratiya srabotala. Graz̧bdanskiye traditsii v sovremennoy Italii. Moscow, Ad Marginem (in Russian).

Polterovich, V. (2012). Reform design: how to search for interim institutions. Montenegrin Journal of Economics, 8(2), $25-$ 44.

Reynolds, P. D. M., Hay, S. M. (1999). Global enterpreneurship, 1999 Executive Report.

Romer, P. M. (1990). Endogenous technological change. The Journal of Political Economy, 98(5), 71-102.

Solow, R. M. (1956). A contribution to the theory of economic growth. The quarterly journal of economics, 70(1), 65-94.

Strielkowski, W., \& Čábelková, I. (2015). Religion, Culture, and Tax Evasion: Evidence from the Czech Republic. Religions, 6(2), 657-669. doi:http://dx.doi.org/10.3390/rel6020657

Yerznkyan, B. A. (2013). Ekonomicheskaya teoriya i matematicheskaya nauka vs. praktika institutsional'nykh preobrazovaniy: istoki neudach i chto delat'? Teoriya i praktika institutsional'nykh preobrazovaniy v Rossii, 27, 6-27 (in Russian). 